\title{
Emerging Roles of Polycomb Silencing in X-Inactivation and Stem Cell Maintenance
}

\author{
I. Muyrers-Chen, I. Hernández-Muñoz, A.H. Lund, M.E. ValK-Lingbeek, \\ P. van der Stoop, E. Boutsma, B. Tolhuis, S.W.M. Bruggeman, P. Taghavi, \\ E. Verhoeven, D. Hulsman, S. Noback, E. Tanger, H. Theunissen, \\ AND M. VAN LOHUIZEN \\ The Netherlands Cancer Institute, Division of Molecular Genetics, \\ 1066 CX Amsterdam, The Netherlands
}

\begin{abstract}
Maintenance of cell identity and cell fate depends on the tight regulation of gene expression patterns in correct time and space. Two families of proteins, the trithorax group (trxG) and the Polycomb group (PcG), use epigenetic mechanisms to faithfully ensure that designated genes are maintained on or off throughout the life of the organism. This maintenance function is imperative to allow the proper development of an organism from a single cell to an organized combination of multifunctional cells. Here, we briefly review the advances achieved in recent years aimed at understanding how members of $\mathrm{PcG}$ and trxG function (for more in-depth reviews, see Otte and Kwaks 2003; Pirrotta et al. 2003; Lund and van Lohuizen 2004; Valk-Lingbeek et al. 2004). Particularly, we will discuss methods that can be employed to uncover additional target genes regulated by $\mathrm{PcG}$ and/or trxG families. Additionally, we will focus on recent results linking PcG regulation with $\mathrm{X}$-inactivation and with stem cell biology.
\end{abstract}

\section{INTRODUCTION}

The Polycomb group (PcG) and trithorax group (trxG) of gene families were first identified in Drosophila as important regulators of homeotic genes, responsible for the development of the body plan. The functional conservation of these protein families from plants and worms to mammals illustrates how basic and essential PcG and trxG regulation is for development. PcG and trxG use epigenetic mechanisms to properly modulate gene expression and to maintain appropriate levels of gene activity over several mitotic divisions. Such epigenetic mechanisms require chromatin structure alterations, independent of a specific DNA sequence, as their mode of action. Both PcG and trxG families act within large protein complexes to execute their function. The initiation complex isolated in Drosophila, designated PRC2 (Polycomb Repressive Complex 2), is $400-600 \mathrm{kD}$ in size and consists of Esc, E(z), Su(z)12, and RbAp48/Nurf-55 (Cao et al. 2002; Kuzmichev et al. 2002; Muller et al. 2002). Recently, variants of this complex, dubbed PRC3, have been characterized, harboring different isoforms of the Esc/EED subunit (Kuzmichev et al. 2004). The second complex, PRC1, contains $\mathrm{Pc}, \mathrm{Ph}, \mathrm{Psc}$, and dRing as its core members (Saurin et al. 2001). In addition, a variety of proteins have been copurified with the PRC1 core complex giving rise to several subcomplexes, which are most probably required for regulation of diverse sets of target genes. Comparable PRC1 and PRC2 complexes have also been isolated in mammals, emphasizing conservation of this ancient family not only in protein structure homology but also in the functional mechanism employed by PcG/trxG members to regulate their target sites (Lund and van Lohuizen 2004). However, owing to duplications of part of the mammalian genome involving PcG genes, dissecting the function of mammalian $\mathrm{PcG} / \mathrm{trxG}$ complexes has proven to be complex because of partial functional redundancy.

In the fly, recent studies showed that both trxG and PcG members can interact with the same CIS elements to insure the proper status of gene activity. The best noted example is the study reporting that both Polycomb $(\mathrm{Pc})$ and GAGA factor (a trxG member) can bind to close but separable entities within the classically defined Fab-7 polycomb response element (PRE) (Francis and Kingston 2001). PREs and TREs (trithorax response elements) have therefore been renamed as Cellular Memory Modules (CMMs) (Cavalli and Paro 1998). Moreover, RNA polymerase and TBP-associated factors (TAFs) can be found simultaneously with Polycomb group members in addition to trxG proteins at a silent locus (Breiling et al. 2001). This supports the idea that the status of gene activity is not merely dependent on the presence or the ability of $\mathrm{PcG}$ or trxG members to change chromatin configuration to prevent activators or repressors from binding (Dellino et al. 2004). Additional levels of regulation certainly must exist to dictate the action of bound $\mathrm{PcG}$ or trxG members in keeping a gene either on or off depending on its developmental context. Based on recent studies in Drosophila, the prevailing model for how PcG silencing works appears to be a looping model, in which the distantly located PREs bound by PcG proteins can interact in a dynamic fashion through multiple low-affinity interactions, with a subset of proteins located at or close to the transcriptional start of homeotic genes (see Schoenfelder and Paro; Schwartz et al.; both this volume). The binding 
of PcG members to distinct elements within PREs/CMMs and the ability of PcG complexes to repress artificial chromatin templates by template bridging support looping models for PcG silencing (Lavigne et al. 2004). Alternative models have recently been proposed in recent reports linking PcG proteins with noncoding RNAs. For instance, it has been suggested that PcG members, rather than altering chromatin structure to block transcription factor accessibility (Francis and Kingston 2001), somehow directly inhibit the ability of the RNA polymerase to transcribe (Dellino et al. 2004). Moreover, it is imaginable that $\mathrm{PcG} /$ trxG members may use their ability to change the packaging of higher-order chromatin to allow RNA polymerase activity at intergenic regions (such as at regulatory regions), generating noncoding RNAs (Hogga and Karch 2002; Rank et al. 2002). The detection of noncoding RNAs in Drosophila, in yeast, and in mammals and the link between chromatin modifiers and the RNAi machinery further substantiate the idea that RNA polymerase activity along the DNA may prevent activator binding (Pal-Bhadra et al. 2002; Lund and van Lohuizen 2004). Whether the noncoding RNAs, generated artificially or physiologically present (microRNAs, siRNAs), have a specific function in targeting $\mathrm{PcG} / \mathrm{trxG}$ protein complexes or in regulating $\mathrm{PcG} / \mathrm{trxG}$ function is an intriguing possibility that deserves to be tested.

In mammals, thus far, PREs/TREs/CMMs have not been described. It is formally possible that because of the diversification of the genome throughout evolution, such as reflected in the vast increase of repetitive elements in mammalian genomes, a different, as of yet elusive targeting mechanism for PcG/trxG exists in mammals. However, given their strong structural and functional conservation, this possibility would be surprising. In this regard, the tethering of PcG/trxG complexes onto chromatin has been best understood in Drosophila. Drosophila pho and pho-like are two PcG proteins that recognize specific DNA sequences and that have been shown recently to recruit E(z)/PRC2 and PRC1complexes to their target sites (Mohd-Sarip et al. 2002; Wang et al. 2004). Importantly, the mammalian homolog of pho, YY1, is also a DNAspecific binding protein and has been described to associate with PRC1 and PRC2 members (Brown et al. 1998; Satijn et al. 2001). Knockdown experiments of YY1 in Xenopus resulted in anterior-posterior patterning defects reminiscent of a classical PcG/trxG mutant (Kwon and Chung 2003). Moreover, the ability of human YY1 to repress target genes in transgenic flies and to partially rescue pho fly mutants further substantiates YY1 as a bona fide PcG member (Atchinson et al. 2003). In summary, a main question in the field is how mammalian $\mathrm{PcG}$ protein complexes are recruited to specific genes and what the identity and genome-wide distribution of these PcG target genes is.

\section{SEARCHING FOR MAMMALIAN PREs/CMMs}

To be able to uncover target genes regulated by $\mathrm{PcG} / \mathrm{trxG}$, an in vivo formaldehyde cross-linking and chromatin immunoprecipitation technique (ChIP) was developed and successfully applied in Drosophila (Or- lando and Paro 1993). However, because of the complexity of the mammalian genome and the increase in repetitive elements relative to the Drosophila genome, using ChIP to identify mammalian PREs has proven to be difficult, especially when applied to screen in a genome-wide fashion (ChIP on DNA microarrays or ChIP on Chip). An additional limitation is the requirement of high-quality antisera, suitable to work after harsh cross-linking conditions. Only very recently, the first successful PRC2 ChIP on Chip with mammalian $\mathrm{CpG}$ island arrays has been reported (Kirmizis et al. 2004). Two alternative techniques have recently been developed that aim at uncovering how various regulatory elements separated over hundreds of kilobases can physically interact to dictate the level of gene expression. The manner in which these regulatory elements come together through "looping" type of interactions reflects the chromatin structure in which a particular gene, whether active or inactive, is embedded. The first technique, called RNA TRAP (tagging and recovery of associated proteins), detects chromatin fragments close to a nascent transcript via RNA fluorescence in situ hybridization (FISH) (Carter et al. 2002). The second method, Chromatin Conformation Capture (3C), depends on computing the frequency of interaction of distant chromatin fragments after formaldehyde cross-linking (Dekker et al. 2002). The 3C method, unlike the RNA TRAP technique, has the advantage that it does not depend on a nascent transcript to uncover chromatin fragment association. The RNA TRAP and $3 \mathrm{C}$ techniques have been used to unravel the molecular nature of how the globin gene cluster is regulated (Carter et al. 2002; Tolhuis et al. 2002). In light of this success, it will be interesting to utilize both RNA TRAP and 3C technology to study in more detail how various PREs/TREs/CMMs may regulate the expression of gene activity and to find support for the proposed looping-type models. However, both RNA TRAP and $3 \mathrm{C}$ require the prior knowledge of target loci for PcG/trxG binding, posing a problem for mammalian applications.

In order to find mammalian $\mathrm{PcG} /$ trxG target genes, an attractive alternative technique to ChIP on Chip is the DamID (Dam identification) methodology (van Steensel et al. 2001). The technique is based on generating fusions of proteins of interest with the Escherichia coli DAM methylase. The exogeneous deposition of methylation marks on adenosine, which does not occur naturally in mammals, can be detected using specific restriction enzymes followed by amplification of DNA fragments enriched for methyl-Adenosines. The resulting pool of amplified DNA would reflect the binding sites of the protein of interest. This pool of DNA is then hybridized to appropriate microarrays, allowing outliers specifically associated with the Dam-fusion protein to be identified on a genome-wide scale. This technique, when applied to PcG proteins in mammalian cells, would provide in theory a complete picture of PcG target genes at a genomic level, but would also allow the analysis for common motifs present in the isolated sequences. Could a common motif identified by this method reflect a true mammalian PRE? A precedent in this respect is the recent demonstration by the Paro lab that a sequence-based search tool could be 
generated, based on ChIP on Chip data, which identified over 100 PREs/TREs in Drosophila, some of which have been functionally verified (Ringrose et al. 2003). As a first step toward more comprehensive analyses, an array encompassing the genomic loci of HOX gene clusters (representing conserved PcG/trxG target genes) would provide a good starting point in mammals. Ultimately, further comparison of DamID profiles with data generated by alternative methods, such as ChIP on Chip experiments, will undoubtedly contribute to our understanding of the mechanism(s) that PcG (and trxG) proteins employ to regulate their target genes.

\section{PcG AND trxG COMPLEXES POSSESS ENZYMATIC ACTIVITIES THAT MODIFY HISTONES/NUCLEOSOMES}

A main finding over the last few years was the demonstration that complexes containing both $\mathrm{PcG}$ and trxG members exhibit enzymatic activities. The targets of these activities have been shown to be histones, although it is conceivable that nonhistone targets may also exist. The various modifications on histones, including phosphorylation, acetylation, methylation, and ubiquitination on different residues, act in a combinatorial manner to regulate gene activity. This so-called "histone code" is thought to provide an epigenetic tag, which serves to recruit appropriate regulators as well as to dictate chromatin compaction (Jenuwein and Allis 2001). The mammalian PRC2 protein Ezh2 sets the repressive methylation mark on $\mathrm{H} 3$ at lysine 27, which is dependent on the association of Ezh2 with PRC2 members Eed and $\mathrm{Su}(\mathrm{z}) 12$ (Cao et al. 2002; Kuzmichev et al. 2002; Muller et al. 2002). In turn, the meK27 mark has been shown to recruit Polycomb via its chromodomain and, thus, initiate sustained silencing by PRC1 (Cao et al. 2002; Czermin et al. 2002; Kuzmichev et al. 2002). An additional level of regulation by the Ezh2 HMT activity is determined by the type of Eed isoforms with which Ezh2 associates. The four Eed isoforms generated by alternate translation sites result in various complexes that direct Ezh2 HMT activity via $\mathrm{PRC} 2$ to the $\mathrm{H} 3$ at lysine 27 or to $\mathrm{H} 1$ at lysine 26 (Kuzmichev et al. 2004). This recent finding is intriguing given the important role of $\mathrm{H} 1$-linker histones in mediating higher-order chromatin folding. Both $\mathrm{H} 1$ and $\mathrm{H} 3$ methylation marks are important for transcriptional repression by Ezh2. These reports are pivotal in our understanding of PcG mechanisms as they provide the first link as to how PRC1 is recruited to target genes via the activity of PRC2.

In contrast, methylation of $\mathrm{H} 3$ at lysine 4 by TRX/MLL and of lysine 4, 9, and 20 by Ash1 is generally correlated with active genes (Beisel et al. 2002; Milne et al. 2002; Nakamura et al. 2002). The recruitment of the remodeling Brahma trxG complex, via the methylation of lysine 4 and double methylation of lysine 9 epigenetic tags and the consequent opening of chromatin by nucleosome repositioning, may be one way in which TRX/MLL and Ash1 enzymatic activities help to induce gene activation (Beisel et al. 2002). An alternative mechanism resulting from the deposition of me-H3K4 marks by trxG members may also include prevention of setting the meK27 mark by $\mathrm{PcG}$ and, thus, prohibition of the establishment of silencing rather than recruiting activators. The finding that double mutants for Trx or Ash1 and PcG members can reconstitute misexpression of Hox genes suggests that at least Trx and Ash1 maintain active genes by indeed functioning as antirepressors rather than classical coactivators (Klymenko and Muller 2004).

\section{IMPLICATIONS OF PcG IN MULTILAYERED GENE SILENCING: THE X-INACTIVATION EXAMPLE}

Arguably the best example of multilayer silencing involving PcG is the recent demonstration that EzH2/PRC2 activity is an important step in the early phases of $\mathrm{X}$-inactivation (Plath et al. 2003; Silva et al. 2003). In mammals, dosage compensation of gene activity of the X-chromosome is normalized between males and females by inactivating one of the two $\mathrm{X}$ chromosomes in female cells (Heard 2004). This process takes place during early development where one of the $\mathrm{X}$ chromosomes is randomly inactivated in the inner cell mass, which gives rise to the embryo proper. The inactivation process is highly dependent on the coating of the inactive $\mathrm{X}$ chromosome by a large noncoding RNA, named Xist (X-inactive-specific transcript), and is influenced by the state of histone acetylation and by DNA methylation. Upon differentiation of embryonic stem (ES) cells, initiation of X-inactivation can be studied, where Xist noncoding RNA is transcribed and recruited to the prospective $\mathrm{Xi}$, and modification of chromatin on the amino-terminal tails of histones $\mathrm{H} 3$ and $\mathrm{H} 4$ is observed. Interestingly, this early stage in the X-inactivation process is still reversible, perhaps reflecting the inherent plasticity of precursor cells. However, later in the differentiation process, inactivation of the $\mathrm{X}$ becomes largely Xist-independent indicating that other silencing mechanisms contribute to assure stable repression of the $\mathrm{Xi}$ during subsequent development.

It was recently demonstrated that at least part of the histone tags on the inactive $\mathrm{X}$ is mediated by the HMT activity of Ezh2/Eed complex PRC2 polycomb (Plath et al. 2003; Silva et al. 2003). The transient binding of Ezh2/Eed complex at the inactive X during the early stages of $\mathrm{X}$-inactivation fits well with its putative function as an initiating repressive complex. Importantly, setting the repressive meK27 mark on the Xi by EzH2/PRC2 was found to be dependent on Xist, although so far no direct binding to the noncoding RNA has been reported (Plath et al. 2003). The trimethylation of H3K27 is localized within distinct domains on the inactive $\mathrm{X}$, which appears to not overlap with the dimethylation of $\mathrm{H} 3 \mathrm{~K} 9$, a mark correlated with facultative heterochromatin (Heard 2004). Worthy to note is that although recruitment of Ezh2/Eed to the inactive $\mathrm{X}$ may be essential for the onset of $\mathrm{X}$-inactivation, it is not enough to maintain silencing. Additional layers of regulation, such as histone acetylation and DNA methylation, must act to synergize with the Xist RNA to silence the $\mathrm{X}$ and/or to contribute in creating a compact chromatin structure that is able to maintain its silencing state over several mitotic divisions. The fact that 
Ezh2/Eed complex binds to the Xi would logically imply that the deposition of trimethylation of H3K27 at the inactive $\mathrm{X}$ should recruit members of the PRC1 complex to the inactive $\mathrm{X}$. This turned out to be correct as we recently detected Bmi1, Ring1B/Rnf2, and hPC2 localization on the inactive $\mathrm{X}$ in mouse and human cells (I. Hernández-Muñoz et al., in prep.). The recruitment of these PRC1 members occurred during the initial stage of $\mathrm{X}$-inactivation following closely the recruitment of Ezh2/Eed. Interestingly, PRC1 binding appeared highly dynamic and dependent on the cell cycle stage, as Bmi-1, Rnf2, and HPC2 were found on the Xi chromosome primarily in early and mid S phase (I. Hernández-Muñoz et al., in prep.). The dynamic kinetics of the recruitment of PRC2 and PRC1 was found in somatic, extraembryonic, and embryonic cells. Such a phenomenon suggests that upon each cell division the reestablishment of the compact silent Xi chromatin needs to be reformed de novo, requiring the recruitment of both PRC2 and PRC1.

The inactive $\mathrm{X}$ has been described to be enriched in histone-variant macroH2A, as is illustrated by specific staining of the Barr body by macroH2A antisera. macroH2A has recently been shown to inhibit accessibility of chromatin to transcription and remodeling factors such as Brahma, thus possibly helping to ensure stable X-inactivation (Angelov et al. 2003). However, a direct role of macroH2A in silencing of the Xi remained obscure. New insight came with the discovery that macroH2A binds to the SPOP protein (Takahashi et al. 2002), and our observation that SPOP also binds to the PRC1 protein Bmil (I. Hernández-Muñoz et al., in prep.). Significantly, SPOP is comprised of both a BTB and a POZ domain, suggesting that SPOP may interact with CULLIN3 to form a functional E3 ubiquitin ligase (see Fig. 1) (Nagai et al. 1997; Furukawa et al. 2003). Subsequent experiments confirmed that SPOP and Bmil as well as SPOP and macroH2A can interact and form active E3 ubiquitin li- gase complexes with CULLIN3 under physiological conditions. Both macroH2A and Bmil themselves are subject to poly- and monoubiquitination by these ligases. Importantly, ubiquitination appeared not to influence the overall stability of Bmil and macroH2A, suggesting that the ubiquitination mark on these proteins serves a regulatory function and that the proteins are not targeted for proteasomal for degradation (I. Hernández-Muñoz et al., in prep.). What the precise molecular function of ubiquitination of Bmil and macroH2A is remains to be fully elucidated. However, the importance of these novel SPOP/CUL3 E3 ligases for X-inactivation was illustrated by a series of RNAi experiments and by using an in vivo assay where a silent GFP reporter is embedded in the inactive X. Knockdown of CULLIN3 and SPOP resulted in a profound delocalization of macroH2A from the inactive $\mathrm{X}$. It thus appears that ubiquitination is a vital feature during the $\mathrm{X}$-inactivation process, which directly or indirectly assists in correct deposition of macroH2A to the inactive $\mathrm{X}$ (Fig. 1). Moreover, knockdown of either macroH2A or CULLIN3 and SPOP in cells carrying a silent GFP reporter on the inactive $\mathrm{X}$ allowed partial reactivation of the GFP reporter. The RNAi-mediated reactivation of the GFP reporter, however, was only observed after mild TSA and 5-azadC treatment of the cells. Taken together, these results suggest that macroH2A, regulated through ubiquitination, represents another level of silencing to the inactive $\mathrm{X}$, acting on top of DNA methylation and histone code changes (I. Hernández-Muñoz et al., in prep.). This multilayered silencing of the inactive $\mathrm{X}$ most probably assures a tight silent chromatin structure that can be stably propagated over several cell generations.

Although functional data demonstrating if and how ubiquitination of Bmil contributes to the silencing of the inactive $\mathrm{X}$ remain to be shown, it is tempting to speculate that modification of Bmil by ubiquitin can help to enhance the formation of silencing complexes required to

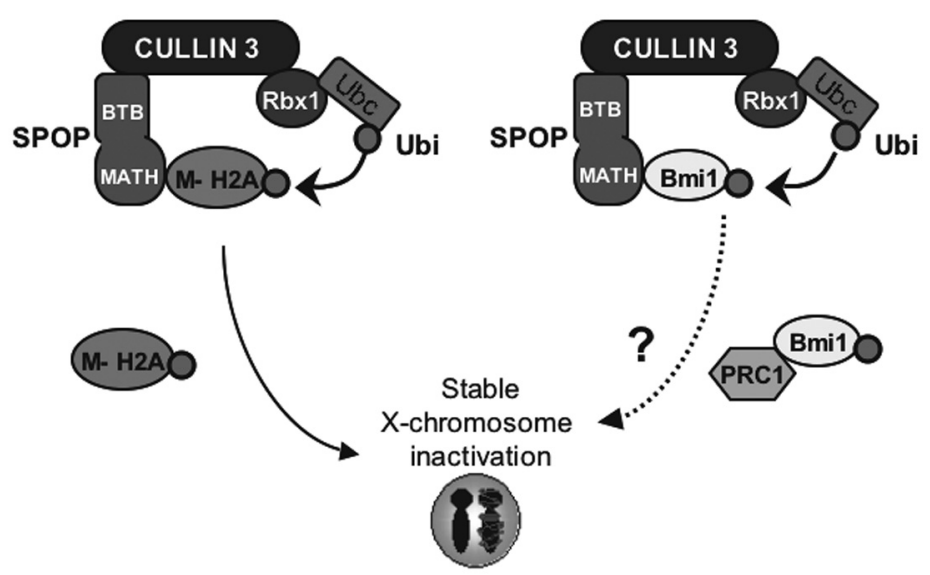

Figure 1. Ubiquitination of MacroH2A represents an additional level of regulation in X-chromosome inactivation. Bmi1 and macroH2A are ubiquitinated by the SPOP/Cul3 E3 ligase. The ubiquitination of macroH2A is important for its proper localization onto the inactive $\mathrm{X}$. The localization of macroH2A is required for the silencing of the inactive $\mathrm{X}$. The $\mathrm{PRC} 1$ complex is recruited to the inactive $\mathrm{X}$ by the HMT activity of the Ezh2/Eed complex. The exact role(s) of PRC1 and of ubiquitination of Bmil in the inactive $\mathrm{X}$ process remains unclear, although it can be speculated that $\mathrm{PRC} 1 / \mathrm{Bmil}$ complexes may be required to stably maintain the compact chromatin of the inactive $\mathrm{X}$ over several mitotic divisions. 
maintain the $\mathrm{X}$ inactive by either changes in Bmil conformation/localization or by recruiting proteins carrying ubiquitin-binding domains (Fig. 1). Moreover, it will be important to investigate if such posttranslation modifications may be a general theme employed by Bmil (and possibly other PcG members) to modulate the extent of its repressive function at other target sites. In this regard, the Caenorhabditis elegans SOP-2 (the corresponding mammalian homolog is Rae28/Mph1) has been recently reported to be sumoylated (an ubiquitin-like molecule) and that this sumoylation is required for SOP-2's ability to localize to nuclear bodies and, most importantly, to enable repression of HOX genes (Zhang et al. 2004). It will be important to further delineate the functional significance of ubiquitinated Bmil as well as to explore Bmil's (and other PRC1 members') role in X-inactivation.

\section{CONNECTIONS AMONG PcG REGULATION, STEM CELL BIOLOGY, AND CANCER FORMATION}

It has often been suggested that stem cells share similarities with cancer cells, most importantly, in their ability to continuously proliferate and in the presence of subsets of cells with undifferentiated characteristics within a heterogeneous tumor cell population (Pardal et al. 2003). Best evidence for the presence of such "cancer stem cells" has been found in several classes of leukemia (Bonnet and Dick 2001; Singh et al. 2003). Given that sustained abnormal expression of Bmil together with c-Myc potently induces leukemia, is there evidence linking Bmi1 regulation (and possibly other PcG members) with stem cell biology? Several recent observations indeed have highlighted this. Deficiency for several PRC1 members, including Bmi1, Mph1/Rae28, M33, and Mel-18, cause severe and progressive reductions in $\mathrm{T}$ and $\mathrm{B}$ cell lymphocytes (van der Lugt et al. 1994; Akasaka et al. 1997; Core et al. 1997; Takihara et al. 1997; Tokimasa et al. 2001). These defects can be understood in light of the recently discovered essential role for both Bmil and Mph1/Rae28 in sustaining the self-renewal capacity of adult hematopoietic stem cells (HSCs) (Ohta et al. 2002; Park et al. 2003). Importantly with respect to its role in cancer formation, similar observations were made with mouse leukemic cells, where Bmil was essential for the maintenance of leukemia following transplantation of primary leukemic cells into secondary recipients (Lessard and Sauvageau 2003). This indicates that a subpopulation of leukemic cancer stem cells rely on Bmi1/PRC1 function for their continuous proliferation.

Extending Bmi-1's role in stem cell biology, Bmi-1 was reported to also be essential for the self-renewal capacity of neural stem cells from the central and peripheral nervous systems and for the proliferation of cerebellar granule neuron precursor cells (CGNPs), which are essential for formation of the cerebellum (Molofsky et al. 2003; Leung et al. 2004). High expression of Bmil was observed in the external granular layer (EGL), a thin layer of cells residing at the surface of the developing cerebellum, and was strongest in proliferating granule cell pre- cursors within the EGL at postnatal days 5-8. The previously observed dramatic and progressive reduction in cerebellum size of Bmil null mice, giving rise to ataxia, tremors, and paralysis due to motorneuron defects, correlates well with the observed reduced proliferation capacity of the CGNPs in vivo and in vitro (Valk-Lingbeek et al. 2004).

Given these observations, obvious following questions are how does Bmi-1 control the ability of stem cells to self-renew, which target genes are implicated, and how in turn is Bmil itself regulated in stem cells? A first clue came from our previous observations, indicating that the Ink4a/Arf tumor-suppressor locus was an important in vivo relevant target for Bmi1/PRC1, when it was observed that the early senescent phenotype exhibited by cells lacking Bmil can be rescued by repressing or deleting the Ink4A/Arf locus. Indeed, Bmil deficiency leads to derepression of the Ink4a/Arf locus, which in turn controls both the Rb and p53 tumor-suppressor pathways and acts as an important tumor-prevention mechanism (for review, see Jacobs and van Lohuizen 2002). Conversely, overexpression of Bmil was shown to hyperrepress the Ink4a/Arf locus, phenocopying loss of these tumor suppressors, explaining why overexpression of Bmil is oncogenic. Hence, the Ink4a/Arf locus is an ideal candidate through which Bmil could exert its effects on stem cell self-renewal. Indeed, through genetic epistasic experiments and functional studies aberrant derepression of the Ink4a/Arf locus was found to contribute to the reduction in self-renewal of stem cells in Bmil knockouts (Jacobs et al. 1999; Molofsky et al. 2003; Park et al. 2003). This suggests that Bmil acts at least in part by repressing the p16/Ink4a and p19/Arf loci postnatally, thus allowing continued proliferation of adult hematopoietic and neural stem cells (Fig. 2).

Apart from implicating the Ink4a/Arf locus as an important downstream target in stem cells, studying the cerebellar phenotypes in Bmil-deficient mice also provided new insight as to how, in turn, Bmil/PRC1 is regulated. As uncontrolled proliferation of cerebellar precursor cells is thought to be the culprit in causing medulloblastoma, a major childhood brain tumor with stem/precursor cell characteristics, and the same precursor cells require Bmi1 for sustained proliferation, BMI1 levels in primary human medulloblastoma samples were investigated. We found high BMI1 overexpression in 8 out of 12 medulloblastomas. Interestingly, these same tumors displayed a constitutive active Sonic Hedgehog (Shh) signaling pathway (Leung et al. 2004). The Shh morphogen and stem cell growth factor has been shown to be required for cerebellar precursor cell proliferation, and mutations in Shh pathway components leading to constitutive signaling have been found in $\pm 25 \%$ of medulloblastomas. We subsequently showed that Shh itself and the downstream Gli1 transcription factor of the Shh pathway induce Bmil expression, providing a direct link between a cell-extrinsic stem cell growth factor and cell-intrinsic epigenetic gene silencing by Bmi1/PRC1. Since the proliferation of CGNPs is induced by the Shh, the reduction in cerebellar granule neurons in the cerebel- 


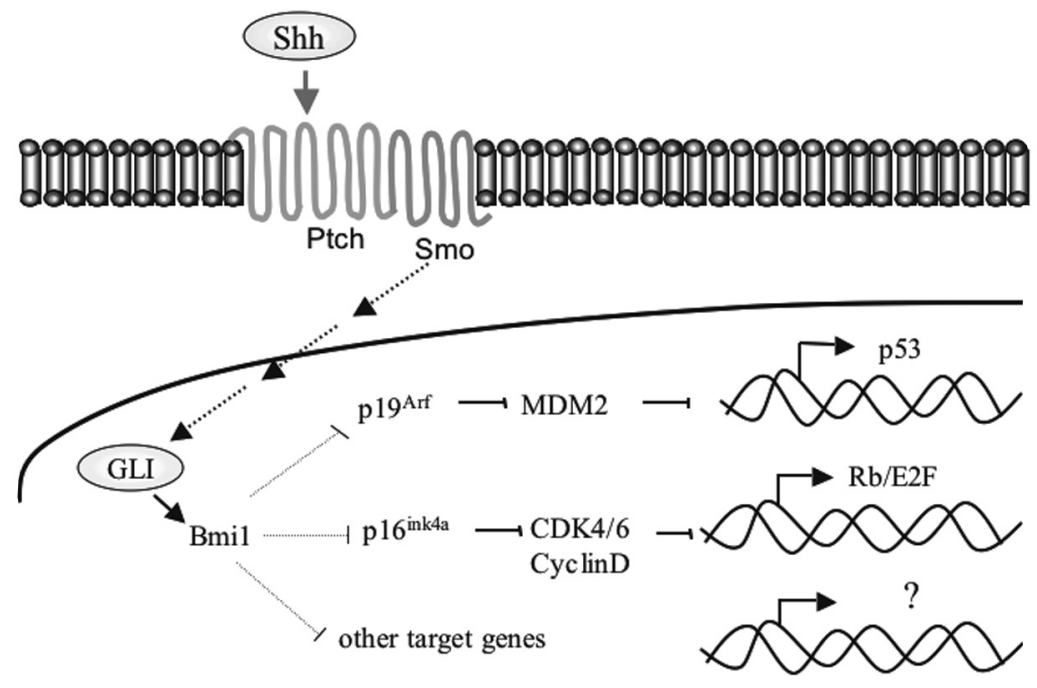

Figure 2. Developmental morphogen Sonic Hedgehog (Shh) acts via Bmil to control stem cell fate. Shh via its receptors, Patched (Ptch) and Smoothened (Smo), signals to downstream transcription factors, GLI, to control the protein level of Bmil. Bmil is required to modulate $\mathrm{p} 16^{\mathrm{ink} 4 \mathrm{a}}$ and $\mathrm{p} 19^{\mathrm{Arf}}$ protein levels to allow stem cells to self-renew via the Rb and $\mathrm{p} 53$ pathways, respectively. The connection among Shh pathway, Bmi1, and the ink4a/Arf locus provides the first example of a developmental signaling pathway impinging on a PcG protein to allow normal stem cell function.

lum of Bmi1 knockout appears to be a result of attenuated Shh signaling. The perfect correlation between Bmil overexpression and sustained activation of the Shh pathway in medulloblastoma suggests that partial activation of the hedgehog pathway may cause high levels of Bmil, which in turn acts together with other Shh responses such as induction of Nmyc, in full proliferation (and perhaps concomitant blocking of differentiation) of cerebellar precursor cells (for review, see Valk-Lingbeek et al. 2004). The Ink4a/Arf locus was shown to be important for the ability of stem cells to self-renew in a Bmil-dependent manner. Taken together, it is plausible that the subset of medulloblastomas that exhibit overexpression of Bmil results at least in part from repression of both the RB (via p16/Ink4a) and the p53 (via p19/Arf) pathways leading to disturbance in the differentiation and proliferation capacity of cerebellar precursors. This hypothesis will be tested in new mouse models.

\section{CONCLUSIONS}

The emerging dynamic role of both PRC1 and PRC2 polycomb protein complexes in X-chromosome inactivation under control of a novel ubiquitin ligase provides new insight in multilayered silencing processes needed for stable repression of larger parts of the genome (Fig. 1). In addition, the role of Bmil in stem cell biology provides the first example of a developmental signaling pathway (Shh) controlling a PcG gene (Bmi1), through which downstream PcG targets (such as Ink4a/Arf) mediate stem cell self-renewal potential (Fig. 2). It is tempting to speculate that additional external signaling pathways may indeed exert their effects in normal cell biology as well as in tumorigenesis via downstream PcG targets. The Shh and Indian hedgehog pathways have been implicated in the regulation of hematopoietic stem cells. Whether Bmi1 is a downstream target of these pathways in other (tumor) cell contexts awaits further study.

\section{REFERENCES}

Akasaka T., Tsuji K., Kawahira H., Kanno M., Harigaya K., Hu L., Ebihara Y., Nakahata T., Tetsu O., Taniguchi M., and Koseki H. 1997. The role of mel-18, a mammalian Polycomb group gene, during IL-7-dependent proliferation of lymphocyte precursors. Immunity 7: 135.

Angelov D., Molla A., Perche P.Y., Hans F., Cote J., Khochbin S., Bouvet P., and Dimitrov S. 2003. The histone variant macroH2A interferes with transcription factor binding and SWI/SNF nucleosome remodeling. Mol. Cell 11: 1033.

Atchinson L., Ghias A., Wilkinson F., Bonini N., and Atchinson M. 2003. Transcription factor YY1 functions as a PcG protein in vivo. $E M B O J .22: 1347$.

Beisel C., Imhof A., Greene J., Kremmer E., and Sauer F. 2002. Histone methylation by the Drosophila epigenetic transcriptional regulator Ash1. Nature 419: 857.

Bonnet D. and Dick J. 2001. Human acute myeloid leukaemia is organized as a hierarchy that originates from a primitive hematopoietic cell. Nat. Med. 3: 730.

Breiling A., Turner B., Bianchi M., and Orlando V. 2001. General transcription factors bind promoters repressed by Polycomb group proteins. Nature 412: 651.

Brown J., Mucci D., Whiteley M., Dirksen M., and Kassis J. 1998. The Drosophila polycomb group gene pleiohomeotic encodes a DNA binding protein with homology to the transcription factor YY1. Mol. Cell 1: 1057.

Cao R., Wang L., Wang H., Xia L., Erdjument-Bromage H., Tempst P., Jones R.S., and Zhang Y. 2002. Role of histone H3 lysine 27 methylation in Polycomb-group silencing. Science 298: 1039 .

Carter D., Chakalova L., Osborne C., Dai Y., and Fraser P. 2002. Long-range chromatin regulatory interactions in vivo. Nat. Genet. 4: 623.

Cavalli G. and Paro R. 1998. The Drosophila Fab-7 chromosomal element conveys epigenetic inheritance during mitosis and meiosis. Cell 93: 505 . 
Core N., Bel S., Gaunt S.J., Aurrand-Lions M., Pearce J., Fisher A., and Djabali M. 1997. Altered cellular proliferation and mesoderm patterning in Polycomb-M33-deficient mice. Development 124: 721 .

Czermin B., Melfi R., McCabe D., Seitz V., Imhof A., and Pirrotta V. 2002. Drosophila enhancer of Zeste/ESC complexes have a histone $\mathrm{H} 3$ methyltransferase activity that marks chromosomal Polycomb sites. Cell 111: 185.

Dekker J., Rippe K., Dekker M., and Kleckner N. 2002. Capturing chromosome conformation. Science 295: 1306.

Dellino G., Schwartz Y., Farkas G., McCabe D., Elgin S., and Pirrotta V. 2004. Polycomb silencing blocks transcription initiation. Mol. Cell 13: 887.

Francis N. and Kingston R. 2001. Mechanisms of transcriptional memory. Nat. Rev. Mol. Cell Biol. 2: 409.

Furukawa M., He Y., Borchers C., and Xiong Y. 2003. Targeting of protein ubiquitination by BTB-Cullin 3-Roc1 ubiquitin ligases. Nat. Cell Biol. 5: 1001.

Heard E. 2004. Recent advance in X-chromosome inactivation. Curr. Opin. Cell Biol. 16: 247.

Hogga I. and Karch F. 2002. Transcription through the iab-7 cisregulatory domain of the bithorax complex interferes with maintenance of polycomb-mediated silencing. Development 129: 4915.

Jacobs J.J. and van Lohuizen M. 2002. Polycomb repression: From cellular memory to cellular proliferation and cancer. Biochim. Biophys. Acta 1602: 151.

Jacobs J.J., Kieboom K., Marino S., DePinho R.A., and van Lohuizen M. 1999. The oncogene and Polycomb-group gene bmi-1 regulates cell proliferation and senescence through the ink4a locus. Nature 397: 164.

Jenuwein T. and Allis C. 2001. Translating the histone code. Science 293: 1074.

Kirmizis A., Bartley S., Kuzmichev A., Margueron R., Reinberg D., Green R., and Farnham P. 2004. Silencing of human polycomb target genes is associated with methylation of histone H3 Lys 27. Genes Dev. 18: 1592.

Klymenko T. and Muller J. 2004. The histone methyltransferases Trithorax and Ash1 prevent transcriptional silencing by Polycomb group proteins. EMBO Rep. 5: 373 .

Kuzmichev A., Jenuwein T., Tempst P., and Reinberg D. 2004. Different EZH2-containing complexes target methylation of histone $\mathrm{H} 1$ or nucleosomal histone H3. Mol. Cell 14: 183.

Kuzmichev A., Nishioka K., Erdjument-Bromage H., Tempst P., and Reinberg D. 2002. Histone methyltransferase activity associated with a human multiprotein complex containing the Enhancer of Zeste protein. Genes Dev. 16: 2893.

Kwon H. and Chung H. 2003. Yin Yang 1, a vertebrate polycomb group gene, regulates antero-posterior neural patterning. Biochem. Biophys. Res. Commun. 306: 1008.

Lavigne M., Francis N., King I., and Kingston R. 2004. Propagation of silencing: Recruitment and repression of native chromatin in trans by polycomb repressed chromatin. Mol. Cell 13: 415.

Lessard J. and Sauvageau G. 2003. Bmi-1 determines the proliferative capacity of normal and leukaemic stem cells. Nature 423: 255 .

Leung C., Lingbeek M., Shakhova O., Liu J., Tanger E., Saremaslani P., van Lohuizen M., and Marino S. 2004. Bmi1 is essential for cerebellar development and is overexpressed in human medulloblastomas. Nature 428: 337.

Lund A.H. and van Lohuizen M. 2004. Polycomb complexes and silencing mechanisms. Curr. Opin. Cell Biol. 16: 239.

Milne T., Briggs S., Brock H., Martin M., Gibbs D., Allis C., and Hess J. 2002. MLL targets SET domain methyltransferase activity to Hox gene promoters. Mol. Cell 10: 1107.

Mohd-Sarip A., Venturini F., Chalkley G.E., and Verrijzer C.P. 2002. Pleiohomeotic can link polycomb to DNA and mediate transcriptional repression. Mol. Cell. Biol. 22: 7473.

Molofsky A.V., Pardal R., Iwashita T., Park I.K., Clarke M.F., and Morrison S.J. 2003. Bmi-1 dependence distinguishes neural stem cell self-renewal from progenitor proliferation. $\mathrm{Na}$ ture 425: 962.

Muller J., Hart C.M., Francis N.J., Vargas M.L., Sengupta A.,
Wild B., Miller E.L., O’Connor M.B., Kingston R.E, and Simon J.A. 2002. Histone methyltransferase activity of a Drosophila Polycomb group repressor complex. Cell 111: 197.

Nagai Y., Kojima T., Muro Y., Hachiya T., Nishizawa Y., Wakabayashi T., and Hagiwara M. 1997. Identification of a novel nuclear speckle-type protein, SPOP. FEBS Lett. 418: 23.

Nakamura T., Mori T., Tada S., Krajewski W., Rozovskaia T., Wassell R., Dubois G., Mazo A., Croce C., and Canaani E. 2002. ALL-1 is a histone methyltransferase that assembles a supercomplex of proteins involved in transcriptional regulation. Mol. Cell 10: 1119

Ohta H., Sawada A., Kim J.Y., Tokimasa S., Nishiguchi S., Humphries R.K., Hara J., and Takihara Y. 2002. Polycomb group gene rae28 is required for sustaining activity of hematopoietic stem cells. J. Exp. Med. 195: 759.

Orlando V. and Paro R. 1993. Mapping Polycomb-repressed domains in the bithorax complex using in vivo formaldehyde cross-linked chromatin. Cell 75: 1187.

Otte A.P. and Kwaks T.H. 2003. Gene repression by Polycomb group protein complexes: A distinct complex for every occasion? Curr. Opin. Genet. Dev. 13: 448.

Pal-Bhadra M., Bhadra U., and Birchler J. 2002. RNAi related mechanisms affect both transcriptional and posttranscriptional transgene silencing in Drosophila. Mol. Cell 9: 315.

Pardal R., Clarke M., and Morrison S. 2003. Applying the principles of stem-cell biology to cancer. Nat. Rev. Cancer 12: 895

Park I.K., Qian D., Kiel M., Becker M.W., Pihalja M., Weissman I.L., Morrison S.J., and Clarke M.F. 2003. Bmi-1 is required for maintenance of adult self-renewing haematopoietic stem cells. Nature 423: 302.

Pirrotta V., Poux S., Melfi R., and Pilyugin M. 2003. Assembly of polycomb complexes and silencing mechanisms. Genetica 117: 191

Plath K., Fang J., Mlynarczyk-Evans S.K., Cao R., Worringer K.A., Wang H., de la Cruz C.C., Otte A.P., Panning B., and Zhang Y. 2003. Role of histone H3 lysine 27 methylation in $\mathrm{X}$ inactivation. Science 300: 131.

Rank G., Prestel M., and Paro R. 2002. Transcription through intergenic chromosomal memory elements of the Drosophila bithorax complex correlates with an epigenetic switch. Mol. Cell. Biol. 22: 8026.

Ringrose L., Rehmsmeier M., Dura J., and Paro R. 2003. Genome-wide prediction of polycomb/trithorax response elements in Drosophila melanogaster. Dev. Cell 5: 759.

Satijn D., Hamer K., den Blaauwen J., and Otte A. 2001. The polycomb group protein EED interacts with YY1, and both proteins induce neural tissue in Xenopus embryos. Mol. Cell. Biol. 21: 1360.

Saurin A., Shao Z., Erdjument-Bromage H., Tempst P., and Kingston R. 2001. A Drosophila Polycomb group complex includes Zeste and dTAFII proteins. Nature 412: 655.

Silva J., Mak W., Zvetkova I., Appanah R., Nesterova T.B., Webster Z., Peters A.H., Jenuwein T., Otte A.P., and Brockdorff N. 2003. Establishment of histone h3 methylation on the inactive X chromosome requires transient recruitment of EedEnx1 polycomb group complexes. Dev. Cell 4: 481.

Singh S., Clarke I., Terasaki M., Bonn V., Hawkins C., Squire J., and Dirks P. 2003. Identification of a cancer stem cell in human brain tumors. Cancer Res. 63: 5821.

Takahashi I., Kameoka Y., and Hashimoto K. 2002. MacroH2A1.2 binds the nuclear protein Spop. Biochim. Biophys. Acta 1591: 63.

Takihara Y., Tomotsune D., Shirai M., Katoh-Fukui Y., Nishii K., Motaleb M.A., Nomura M., Tsuchiya R., Fujita Y., Shibata Y., Higashinakagawa T., and Shimada K. 1997. Targeted disruption of the mouse homologue of the Drosophila polyhomeotic gene leads to altered anteroposterior patterning and neural crest defects. Development 124: 3673.

Tokimasa S., Ohta H., Sawada A., Matsuda Y., Kim J.Y., Nishiguchi S., Hara J., and Takihara Y. 2001. Lack of the Polycomb-group gene rae28 causes maturation arrest at the early B-cell developmental stage. Exp. Hematol. 29: 93. 
Tolhuis B., Palstra R., Splinter E., Grosvel F., and de Laat W. 2002. Looping and interaction between hypersensitive sites in the active $\beta$-globin locus. Mol. Cell 10: 1453.

Valk-Lingbeek M., Bruggeman S., and van Lohuizen M. 2004. Stem cells and cancer: The polycomb connection. Cell 118: 409.

van der Lugt N.M., Domen J., Linders K., van Roon M., Robanus-Maandag E., te Riele H., van der Valk M., Deschamps J., Sofroniew M., van Lohuizen M., and Berns A. 1994. Posterior transformation, neurological abnormalities, and severe hematopoietic defects in mice with a targeted dele- tion of the bmi-1 proto-oncogene. Genes Dev. 8: 757.

van Steensel B., Delrow J., and Henikoff S. 2001. Chromatin profiling using targeted DNA adenine methyltransferase. Nat. Genet. 27: 304.

Wang L., Brown J.L., Cao R., Zhang Y., Kassis J.A., and Jones R.S. 2004. Heirarchical recruitment of polycomb group silencing complexes. Mol. Cell 14: 637.

Zhang H., Smolen G., Palme R., Christoforou A., van den Heuvel S., and Haber D. 2004. SUMO modification is required for in vivo Hox gene regulation by the Caenorhabditis elegans Polycomb group protein SOP-2. Nat. Genet. 36: 507. 


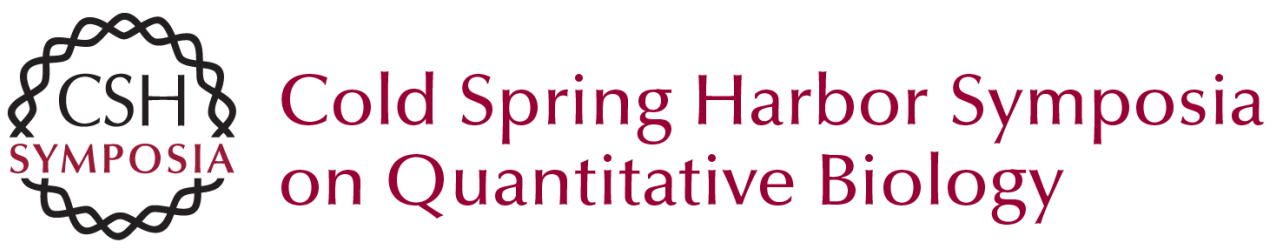

\section{Emerging Roles of Polycomb Silencing in X-Inactivation and Stem Cell Maintenance}

I. MUYRERS-CHEN, I. HERNÁNDEZ-MUÑOZ, A.H. LUND, et al.

Cold Spring Harb Symp Quant Biol 2004 69: 319-326

Access the most recent version at doi:10.1101/sqb.2004.69.319

References This article cites 59 articles, 17 of which can be accessed free at: http://symposium.cshlp.org/content/69/319.full.html\#ref-list-1

\section{License}

Email Alerting

Receive free email alerts when new articles cite this article - sign up in the Service box at the top right corner of the article or click here. 